\title{
STUDI POTENSI LAHAN DAN AREA PERUMAHAN UNTUK IMPLEMENTASI PEMBANGKIT LISTRIK TENAGA SURYA (PLTS) DI WILAYAH SERANG DAN CILEGON BANTEN
}

\author{
Suhendar $^{1}$, Budi Raharjo ${ }^{2}$, Alimuddin ${ }^{3}$, Hady Sutjipto ${ }^{4}$ \\ 1,2,3 Jurusan Teknik Elektro, Fakultas Teknik, Universitas Sultan Ageng Tirtayasa \\ ${ }^{4} J u r u s a n$ Ekonomi Pembangunan, Fakultas Ekonomi dan Bisnis, Universitas Sultan Ageng Tirtayasa \\ e-mail: suhendar@untirta.ac.id, budiraharjo@gmail.com, alimuddin@yahoo.com, hady.sutjipto@gmail.com
}

\begin{abstract}
Electrical energy requirements increase as population growth and technological development. Increased triggered also by the rate of energy demand growth of $6.86 \%$ annually. Energy needs largely derived from non-renewable energy which has its limitations and is not environmentally friendly. Therefore we need a renewable energy alternative and environmentally friendly. One such alternative is the use of solar energy as a power plant that was converted by solar panels. To do with it, this study aims to determine the potential for, contributions and aspects of the cost of solar energy as a power plant in a residential neighborhood Serang Cilegon. The results showed that the development and implementation of SPP in an open area can generate a total capacity $84971.481 \mathrm{kWp}$. The greatest potential in the residential Highland Park with a capacity of $50370.802 \mathrm{kWp}$ that have an energy conversion amounted to 36,707,706 $\mathrm{kWh} /$ year. While the supply of energy $33750047 \mathrm{kWh} / \mathrm{year}$ will be able to contribute to meet all the needs of the household burden. While in Pondok Cilegon Indah residential area with a capacity of $123.032 \mathrm{kWp}$ with a conversion of energy $98387 \mathrm{kWh} /$ year. Energy supply $90452 \mathrm{kWh} / \mathrm{year}$ to contribute $0.76 \%$ of the burden of households. PLTS investment with life project for 25 years for a return on investment costs takes as long as 25 years and 1 month as of the beginning of the project so as not feasible investment.
\end{abstract}

Keywords : Banten, Cilegon, Hydroelectric, Potential, Serang, Solar Energy, Solar Panels,

\section{INTISARI}

Kebutuhan energi listrik semakin meningkat seiring pertumbuhan penduduk dan perkembangan teknologi. Peningkatan dipicu juga oleh laju pertumbuhan kebutuhan energi 6,86\% setiap tahunnya. Kebutuhan energi sebagian besar berasal dari energi tak terbarukan yang memiliki keterbatasan dan tidak ramah lingkungan. Oleh karena itu diperlukan alternatif energi terbarukan dan ramah lingkungan. Salah satu alternatif tersebut adalah pemanfaatan energi matahari sebagai pembangkit listrik yang dikonversi dengan panel surya. Kaitannya dengan itu, penelitian ini bertujuan untuk mengetahui potensi, kontribusi dan aspek biaya energi matahari sebagai pembangkit listrik di kawasan perumahan Serang Cilegon. Hasil penelitian menunjukkan bahwa pengembangan dan implementasi PLTS di area terbuka dapat membangkitkan kapasitas total $84971,481 \mathrm{kWp}$. Potensi terbesar pada perumahan Highland Park dengan kapasitas sebesar 50370,802 kWp yang memiliki energi konversi sebesar $36707706 \mathrm{kWh}$ per tahun. Sedangkan energi suplai $33750047 \mathrm{kWh}$ pertahun akan mampu berkontribusi memenuhi seluruh kebutuhan beban rumah tangga. Sementara di wilayah perumahan Pondok Cilegon Indah dengan kapasitas sebesar 123,032 kWp dengan energi konversi $98387 \mathrm{kWh}$ per tahun. Energi suplai $90452 \mathrm{kWh}$ per tahun mampu memberikan kontribusi 0,76\% terhadap beban rumah tangga. Investasi PLTS dengan project life selama 25 tahun untuk pengembalian biaya investasi membutuhkan waktu selama 25 tahun 1 bulan terhitung awal berdirinya proyek sehingga tidak layak secara investasi.

Kata kunci : Potensi, PLTS, Energi Matahari, Panel Surya, Serang, Cilegon, Banten

\section{PENDAHULUAN}

Kebutuhan energi listrik semakin meningkat seiring pertumbuhan penduduk dan perkembangan teknologi di semua bidang. Pemenuhan kebutuhan energi tersebut sebagian besar berasal dari batu bara, minyak bumi dan gas alam yang sangat terbatas karena termasuk energi tak terbarukan. Dengan kebutuhan energi yang begitu banyak bahan bakar fosil dan gas bumi tidak mampu mencukupi semua kebutuhan, maka untuk memenuhi kebutuhan tersebut dimanfaatkan energi terbarukan yaitu energi yang tidak akan ada habisnya. Selain keterbatasan tersebut batu bara dan minyak bumi menimbulkan pencemaran lingkungan. Indonesia yang merupakan negara yang berkomitmen dalam menurunkan global 
warming. Sehingga perlukan upaya nyata untuk mendukung komitmen tersebut. Untuk mengatasi kebutuhan energi dan mendukung penurunan global warming diperlukan alternatif sumber energi lain yang berasal dari energi terbarukan dan ramah lingkungan [9]. Salah satu energi terbarukan serta ramah lingkungan yaitu energi matahari. Beban energi listrik terdiri atas beban rumah tangga, industri, bisnis, sosial, gedung kantor pemerintahan dan penerangan jalan umum. Akan tetapi secara nasional beban energi terbesar adalah beban rumah tangga yang mencapai $41,17 \%$. Untuk mengatasi hal tersebut maka potensi pemanfaatan ruang terbuka dikawasan perumahan layak untuk dianalisis dari segi potensi, kontribusi maupun investasi pengembangan PLTS di Banten khususnya pada kawasan perumahan Serang Cilegon. Adapun tujuan dari penelitian ini adalah mengetahui potensi energi matahari sebagai pembangkit listrik di kawasan perumahan Serang - Cilegon, mengetahui analisa biaya (cost) pemanfaatan energi matahari sebagai pembangkit listrik dan menentukan kontribusi energi matahari sebagai pembangkit listrik di kawasan perumahan Serang Cilegon.

\section{TINJAUAN PUSTAKA}

Energi atau tenaga adalah kemampuan suatu benda untuk melakukan usaha atau kerja. Menurut hukum kekekalan energi, energi tidak dapat diciptakan dan tidak dapat dimusnahkan. Energi matahari berasal dari proses fusi termonuklir yang mengubah oksigen menjadi helium pada inti matahari. Untuk mengkonversi energi matahari menjadi energi listrik adalah dengan pemanfaatan panel surya. Untuk mengetahui besarnya daya sesaat yang dihasilkan panel surya maka diperlukan data daya yang diterima permukaan panel terhadap besarnya intensitas cahaya matahari. Persamaan energi adalah sebagai berikut [2].

$$
\mathrm{W}=\mathrm{P} \times \mathrm{t}
$$

Daya tersebut merupakan perkalian antara luas permukaan panel surya dengan besarnya intensitas cahaya matahari yang diterima untuk waktu tertentu. Persamaannya adalah sebagai berikut [5].

$$
P_{\text {in }}=\operatorname{Ir} x A
$$

Tegangan keluaran atau output dari panel surya merupakan perkalian antara arus hubung singkat $\left(\mathrm{I}_{\mathrm{SC}}\right)$, tegangan rangkaian terbuka $\left(\mathrm{V}_{\mathrm{OC}}\right)$ dan Fill Factor (FF). Persamaannya adalah sebagai berikut [2]:

$$
P_{\mathrm{out}}=I_{\mathrm{SC}} x V_{\mathrm{OC}} x F F
$$

nilai FF diperoleh dengan persamaan [2]:

$$
F F=\frac{\left(V_{\mathrm{MPP}} x I_{\mathrm{MPP}}\right)}{V_{\mathrm{OC}} x I_{\mathrm{SC}}}
$$

Adapun persamaan efisiensi sesaat yang terukur sebagai berikut [1].

$$
\eta=\frac{\text { Pout }}{\text { Pin }} \times 100 \%
$$

Dengan demikian maka persamaan besarnya efisiensi pembangkitan sesaat panel surya [5] adalah sebagai berikut:

$$
\eta_{\text {sesaat }}=\frac{P}{\operatorname{Ir} \times A} \times 100 \%
$$

Kapasitas daya yang dibangkitkan PLTS (Watt Peak) dapat dihitung dengan persamaan sebagai berikut [7]:

$$
P_{\text {Watt peak }}=\text { Area array } x \text { PSI } x \eta p v
$$

Berdasarkan daya daya pembangkitan PLTS maka jumlah panel yang diperlukan dalam pengembangan PLTS dihitung dengan persamaan sebagai berikut [8].

$$
\text { Jumla panel surya }=\frac{P_{\text {Watt Peak }}}{P_{\mathrm{MPP}}}
$$

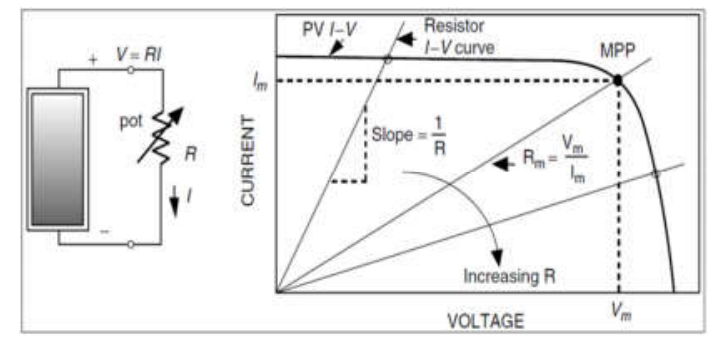

Gambar 1. karakteristik pembebanan resistif [5]

Kapasitas total baterai (Ah) yang dibutuhkan pada sistem PLTS dapat dihitung dengan persamaan sebagai berikut [7].

$$
A_{\text {baterai }}=I=\frac{E_{L}}{(\% \operatorname{Max} D O D) \times(T C F) \times V_{\text {baterai }}} \times A D
$$

Kapasitas minimum inverter diperoleh dengan mempertimbangkan faktor future margin, error margin dan capacity factor. 
Adapun persaaman kapasitas minimum inverter adalah sebagai berikut [10]:

$$
P=\frac{\mathrm{E}_{\mathrm{L}} \times F M \times E M}{C F}
$$

Faktor pemulihan modal dapat diperoleh dengan persamaan sebagai berikut [8].

$$
C R F=\frac{i(1+i)^{\mathrm{n}}}{(1+i)^{\mathrm{n}}-1}
$$

Biaya energi PLTS dapat diperoleh dengan persamaan sebagai berikut [7]:

$$
C O E=\frac{L C C X C R F}{A k W h}
$$

Net Present Value (NPV) merupakan seluruh aliran kas bersih dinilaisekarangkan atas dasar faktor diskonto (discount factor). Adapun persamaannya adalah sebagai berikut [3].

$$
N P V=\sum_{t=1}^{n}\left(\frac{N C F t}{(1+r)}\right)+I I
$$

\section{METODE PENELITIAN}

Langkah penelitian potensi dan kontribusi energi matahari sebagai pembangkit listrik di kawasan perumahan Serang Cilegon dapat diamati pada diagram alir sebagai berikut.

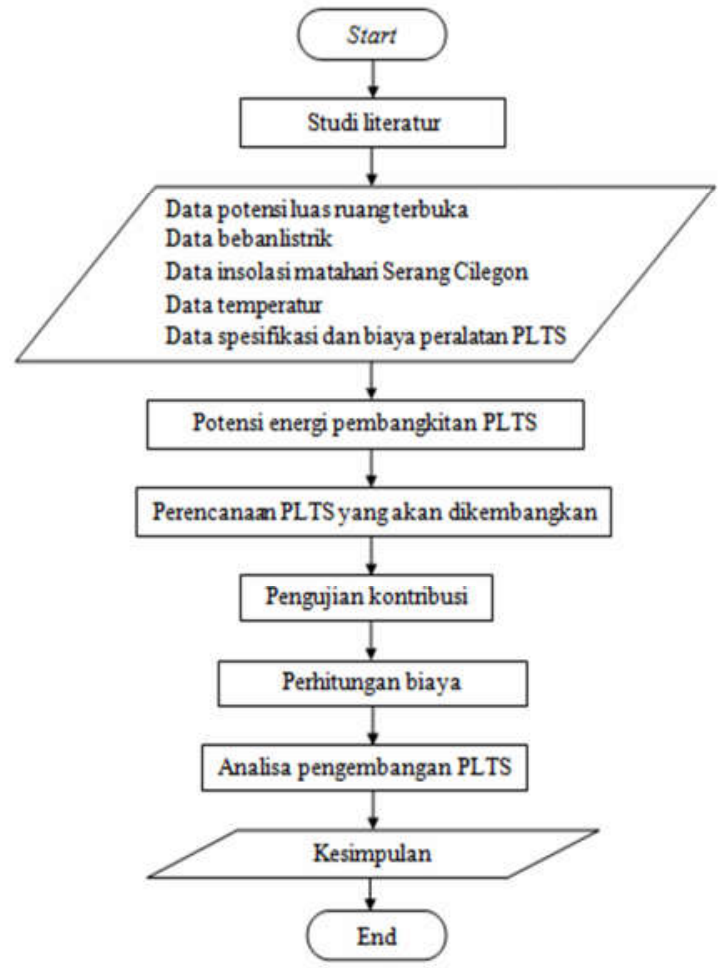

Gambar 2. Diagram alir perencanaan penelitian
Penjelasan dari diagram alir tersebut adalah sebagai berikut :

Tahap pertama yaitu pengumpulan data data-data pendukung yaitu data luas ruang terbuka pada masing-masing perumahan di kawasan Serang - Cilegon, data beban listrik di kawasan perumahan Serang - Cilegon serta pengukuran dan pengamatan langsung data insolasi matahari, energi konversi panel surya dan temperatur panel surya di kawasan perumahan Serang - Cilegon. Data luas ruang terbuka diperoleh dari dinas masing-masing daerah yaitu Dinas Tata Kota Cilegon, Dinas Tata Kota - Serang dan Dinas Tata Ruang dan Bangunan Kabupaten Serang.

Tahap yang kedua yaitu perhitungan potensi energi pembangkitan PLTS dilakukan berdasarkan luas area potensi PLTS untuk wilayah Serang Cilegon.

Tahap yang ketiga yaitu perencanaan pembangkit listrik tenaga surya dilakukan dengan menentukan sistem yang digunakan pada pembangkit listrik. Adapun perencanaan PTLS meliputi penentuan luas area potensi pengembangan PLTS, menentukan kapasitas inverter, menentukan orientasi panel surya, menentukan kapasitas baterai.

Tahap ke empat pengujian kontribusi PLTS dilakukan dengan menggunakan Software PvSyst. Adapun tahapan pengujian kontribusi PLTS meliputi beberapa tahapan diantaranya penunjukan proyek, orientasi dan sistem.

Tahap kelima yaitu perhitungan biaya pada sistem PLTS meliputi biaya investasi awal, Biaya operasional dan pemeliharaan, biaya siklus hidup, dan biaya Energi dan biaya pengembalian investasi.

\section{HASIL DAN PEMBAHASAN}

\section{A. Hasil Pengukuran Energi Matahari}

Pengukuran energi matahari dilakukan di beberapa titik untuk memperoleh energi ratarata yang dihasilkan panel surya. Lokasi pengukuran yaitu pada perumahan Krakatau Steel (5 59'49" LS) - Kota Cilegon, Bumi Waringin Asri (603'56" LS) - Kabupaten Serang, Highland Park $\left(6^{0} 08^{\prime} 10^{\prime \prime}\right.$ LS) - Kota Serang dan Bumi Cikande Indah (6 $6^{0} 12^{\prime} 55^{\prime \prime}$ LS) Kabupaten Serang. 
Adapun hasil pengukuran pembebanan panel surya dengan menggunakan baterai adalah sebagai berikut.

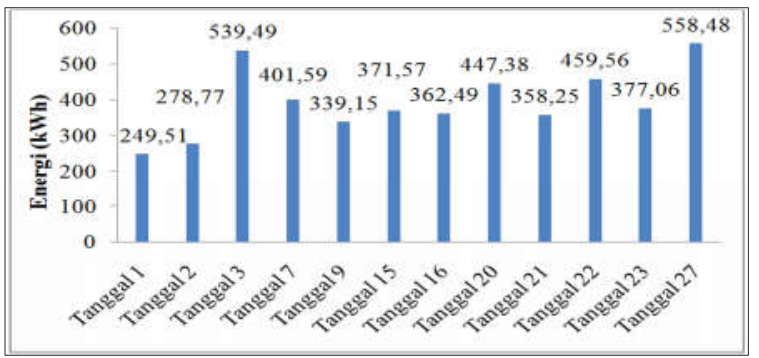

Gambar 3. Pengujian pengisian baterai Maret 2013

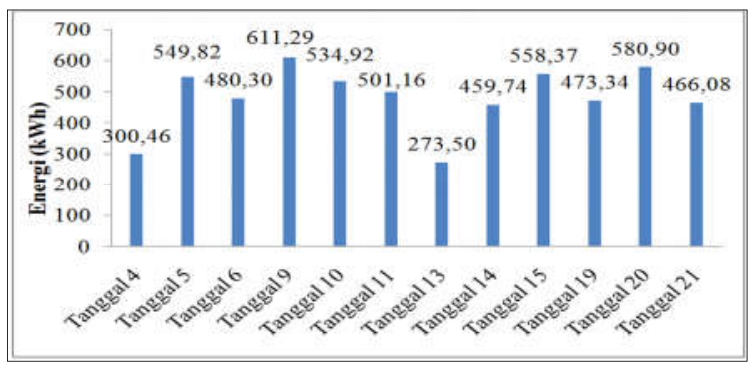

Gambar 4. Pengujian pengisian baterai April 2014

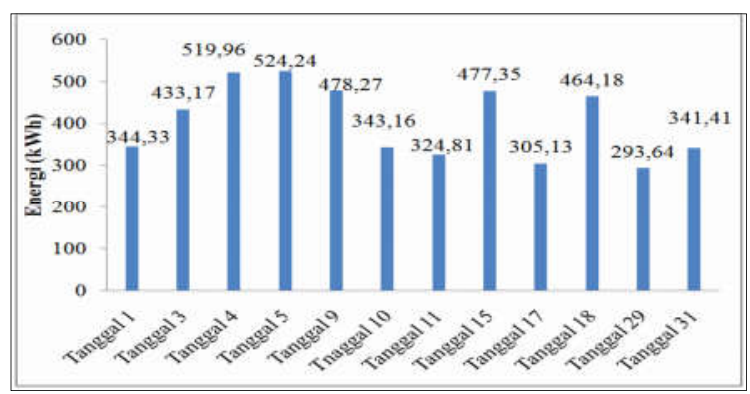

Gambar 5. Pengujian pengisian baterai Mei 2014

Pengisian baterai selama tiga bulan yaitu pada bulan Maret, April dan Mei tersebut dilakukan dengan menghubungkan baterai dengan keluaran panel surya yang di kontrol dengan Solar Charger Controller sejak pukul 07.00 hingga pukul 18.00. Hasil pengujian yang dilakukan diperoleh bahwa daya pengisian terbesar pada bulan Maret sebesar 96,18 Watt, daya pengisian terbesar pada bulan April sebesar 101,02Watt dan daya pengisian terbesar pada bulan Mei sebesar 88,08 Watt. Daya pengisian baterai sangat dipengaruhi oleh intensitas cahaya matahari yang diterima panel surya.

Adapun salah satu hasil pengujian temperatur panel surya adalah sebagai berikut.

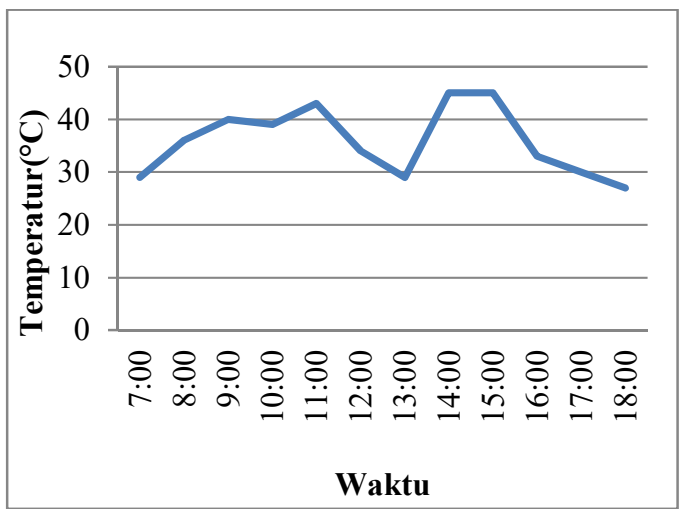

Gambar 6. Grafik pengukuran temperatur pada 19 April 2014

Pengukuran temperatur permukaan panel surya dilakukan selama 3 bulan yaitu pada bulan Maret, April dan Mei. Pengujian tersebut dilakukan dengan menggunakan thermocouple dengan menempelkan ujung thermocouple pada permukaan panel surya. Berdasarkan pengujian yang dilakukan diperoleh bahwa temperatur tertinggi pada permukaan panel surya selama bulan Maret adalah sebesar $48^{\circ} \mathrm{C}$, temperatur tertinggi pada permukaan panel surya selama bulan April sebesar $62^{\circ} \mathrm{C}$ dan temperatur tertinggi pada permukaan panel surya selama bulan Mei sebesar $57^{\circ} \mathrm{C}$.

Pengujian daya maksimum $\left(\mathrm{P}_{\mathrm{MPP}}\right)$ dengan menggunakan beban variable resistive dari 1 ohm hingga $100 \mathrm{ohm}$ yang terhubung dengan ke output panel surya dapat diamati pada salah satu hasil pengukuran sebagai berikut.

Tabel 1. Pengukuran beban resistif

\begin{tabular}{cccc}
\hline $\mathbf{R}(\mathbf{\Omega})$ & $\mathbf{V}(\mathbf{V})$ & $\mathbf{I}(\mathbf{A})$ & $\mathbf{P}(\mathbf{W})$ \\
\hline 1 & 10,27 & 5,73 & 58,85 \\
2 & 15,02 & 5,42 & 81,41 \\
3 & 16,98 & 4,54 & 77,09 \\
4 & 17,75 & 3,74 & 66,39 \\
5 & 18,16 & 3,16 & 57,39 \\
6 & 18,41 & 2,74 & 50,44 \\
7 & 18,59 & 2,41 & 44,80 \\
8 & 18,69 & 2,15 & 40,18 \\
9 & 18,84 & 1,94 & 36,55 \\
10 & 18,94 & 1,72 & 32,58 \\
20 & 19,27 & 0,92 & 17,73 \\
30 & 19,33 & 0,64 & 12,37 \\
40 & 19,44 & 0,50 & 9,72 \\
50 & 19,47 & 0,38 & 7,40 \\
60 & 19,50 & 0,32 & 6,24 \\
70 & 19,51 & 0,27 & 5,27 \\
80 & 19,53 & 0,24 & 4,69 \\
90 & 19,54 & 0,21 & 4,10 \\
100 & 19,54 & 0,20 & 3,91 \\
\hline
\end{tabular}


Berdasarkan hasil pengukuran tersebut diperoleh $\mathrm{P}_{\mathrm{MPP}}$ sebesar 81,41 Watt pada beban $2 \Omega$ dengan tegangan 15,02 Volt dan arus 5,42 Ampere. Tegangan dan arus tersebut merupakan tegangan keluaran maksimum $\left(\mathrm{V}_{\mathrm{MP}}\right)$ dan Arus keluaran maksimum $\left(\mathrm{I}_{\mathrm{MP}}\right)$. Berdasarkan hasil pengukuran pada pukul 10.00 April 2014 Tegangan open circuit $\left(\mathrm{V}_{\text {OC }}\right)$ yang terukur 19,80 Volt dan arus short circuit $\left(\mathrm{I}_{\mathrm{SC}}\right)$ 5,77 Ampere. Berdasarkan Tabel 2 dapat digambarkan pada grafik sebagai berikut.

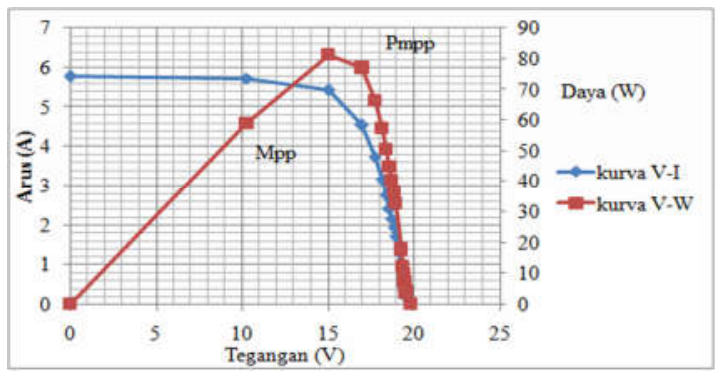

Gambar 7. Kurva $\mathrm{P}_{\mathrm{MPP}}$

Dari hasil pengukuran tersebut maka perhitungan Fill Factor (FF) berdasarkan persamaan (4) adalah sebagai berikut.

$$
\begin{gathered}
F F=\frac{\left(V_{\mathrm{mpp}} \times I_{\mathrm{mpp}}\right)}{V_{\mathrm{oc}} \times I_{\mathrm{sc}}} \\
=\frac{(15,02 \times 5,42)}{19,80 \times 5,77}=\frac{81,4084}{114,246}=0,71257
\end{gathered}
$$

Dari hasil perhitungan tersebut maka daya keluaran panel surya diperhitungkan berdasarkan persamaan (3) adalah sebagai berikut.

$$
\begin{aligned}
P_{\text {out }} & =V_{\mathrm{OC}} \times I_{\mathrm{SC}} \times F F \\
& =19,80 \mathrm{~V} \times 5,77 \text { A } \times 0,71257 \\
& =81,4083 \mathrm{Watt}
\end{aligned}
$$

Intensitas cahaya matahari yang terukut pada Solar Power Meter sebesar $821 \mathrm{~W} / \mathrm{m}^{2}$ dan luas permukaan panel $0,7936 \mathrm{~m}^{2}$. Sehingga efisiensi sesaat konversi pembangkitan panel surya dapat diperhitungkan dengan persamaan (6) sebagai berikut.

$$
\begin{aligned}
\eta_{\text {sesaat }} & =\frac{P}{\operatorname{Ir} x A} \times 100 \% \\
& =\frac{81,4083 W}{821 \mathrm{~W} / \mathrm{m}^{2} \times 0,7936 \mathrm{~m}^{2}} \times 100 \% \\
& =12,49 \%
\end{aligned}
$$

\begin{tabular}{|c|c|c|}
\hline Tanggal & $\begin{array}{c}\text { Energi } \\
\text { Konversi } \\
\text { (Wh/Hari) }\end{array}$ & $\begin{array}{c}\text { Insolasi } \\
\text { Matahari } \\
\left(\text { Wh/m } / m^{2} / h a r i\right)\end{array}$ \\
\hline 1 Maret 2014 & 268,15 & 2642 \\
\hline 2 Maret 2014 & 295,08 & 3285 \\
\hline 3 Maret 2014 & 581,38 & 6383 \\
\hline 7 Maret 2014 & 373,27 & 4286 \\
\hline 9 Maret 2014 & 371,55 & 3916 \\
\hline 15 Maret 2014 & 423,88 & 4323 \\
\hline 20 Maret 2014 & 524,52 & 5252 \\
\hline 21 Maret 2014 & 392,29 & 3971 \\
\hline 22 Maret 2014 & 478,72 & 4919 \\
\hline 16 Maret 2014 & 448,24 & 4692 \\
\hline 23 Maret 2014 & 466,15 & 4807 \\
\hline 27 Maret 2014 & 579,22 & 6044 \\
\hline Energi Rata-rata & 396,44 & 4588,25 \\
\hline
\end{tabular}

Berdasarkan hasil perhitungan diperoleh energi konversi panel surya yang dapat diamati pada Tabel 3 dan 4 .
Tabel 2. Energi konversi panel surya pada bulan Maret 2014

Tabel 3. Pengukuran energi konversi panel surya pada bulan April 2014

\begin{tabular}{rcc}
\hline Tanggal & $\begin{array}{c}\text { Energi } \\
\text { Konversi } \\
\text { (Wh/Hari) }\end{array}$ & $\begin{array}{c}\text { Insolasi } \\
\text { Matahari } \\
\left(\boldsymbol{W h} / \boldsymbol{m}^{2} / \text { hari }\right)\end{array}$ \\
\hline 9 April 2014 & 650,25 & 6574 \\
10 April 2014 & 526,36 & 5681 \\
11 April 2014 & 516,05 & 5325 \\
13 April 2014 & 288,08 & 3029 \\
20 April 2014 & 624,26 & 6477 \\
21 April 2014 & 503,11 & 4853 \\
14 April 2014 & 482,45 & 5115 \\
15 April 2014 & 573,79 & 6131 \\
19 April 2014 & 484,96 & 4875 \\
4 April 2014 & 315,40 & 3127 \\
5 April 2014 & 573,53 & 5690 \\
6 April 2014 & 511,59 & 5183 \\
\hline Energi Rata-rata & $\mathbf{4 9 6 , 2 8}$ & $\mathbf{5 1 8 6 , 3 3}$ \\
\hline
\end{tabular}

Tabel 4. Pengukuran energi konversi panel surya pada bulan Mei 2014

\begin{tabular}{rcc}
\hline \multicolumn{1}{c}{ Tanggal } & $\begin{array}{c}\text { Energi } \\
\text { Konversi } \\
\text { (Wh/Hari) }\end{array}$ & $\begin{array}{c}\text { Insolasi } \\
\text { Matahari } \\
\left(\boldsymbol{W h} \mathbf{m}^{2} \text { /hari }\right)\end{array}$ \\
\hline 1 Mei 2014 & 365,15 & 3711 \\
\hline 17 Mei 2014 & 313,53 & 3476 \\
18 Mei 2014 & 476,58 & 5266 \\
5 Mei 2014 & 553,98 & 5650 \\
9 Mei 2014 & 499,31 & 5292 \\
10 Mei 2014 & 341,52 & 3731 \\
15 Mei 2014 & 496,78 & 5526 \\
29 Mei 2014 & 312,71 & 3230 \\
31 Mei 2014 & 360,24 & 3809 \\
3 Mei 2014 & 432,32 & 4645 \\
4 Mei 2014 & 601,45 & 6299 \\
11 Mei 2014 & 328,08 & 3561 \\
\hline Energi Rata-rata & 423,47 & 4516 \\
\hline
\end{tabular}




\section{B. Kapasitas Inverter}

Perhitungan kapasitas inverter dilakukan untuk memperoleh kapasitas inverter yang sesuai beban yang akan disuplai PLTS. Beban energi yang akan disuplai inverter dipengaruhi oleh luas area panel surya, insolasi matahari (Gav), efisiensi panel surya ( $\eta p v)$, faktor koreksi temperatur, dan efisiensi. Hasil pengukuran diperoleh temperatur maksimum panel surya mencapai $62^{\circ} \mathrm{C}$. Selisih kenaikan temperatur tersebut terhadap temperatur standar panel surya $\left(25^{\circ}\right)$ yaitu sebesar $37^{\circ} \mathrm{C}$. Penurunan daya keluaran panel surya terhadap kenaikan temperatur tersebut adalah sebagai berikut.

$$
\begin{aligned}
P_{\text {saat suhu naik t }{ }^{0} \mathrm{C}} & =\left[\left(0,5 \% /{ }^{0} \mathrm{C}\right) \times P_{\mathrm{MPP}} \times t^{0} \mathrm{C}\right] \\
& =\left[\left(0,5 \% /{ }^{\circ} \mathrm{C}\right) \times 100 \mathrm{Wp} \times 37^{0} \mathrm{C}\right] \\
& =18,5 \mathrm{~W}
\end{aligned}
$$

Selisih penurunan daya tersebut menyebabkan penurunan daya maksimum $\mathrm{P}_{\mathrm{MPP}}$ saat kenaikan $37^{\circ} \mathrm{C}$ yaitu sebagai berikut.

$$
\begin{aligned}
\mathrm{P}_{\mathrm{MPP} \text { saat suhu naik } \mathrm{t} C} \mathrm{C} & =\mathrm{P}_{\mathrm{MPP}}-\mathrm{P}_{\text {saat suhu naik } \mathrm{t} C} \\
& =100 \mathrm{~W} \quad 18,5 \mathrm{~W} \\
& =81,5 \mathrm{~W}
\end{aligned}
$$

Berdasarkan hasil perhitungan penurunan daya maksimum $\mathrm{P}_{\mathrm{MPP}}$ saat kenaikan $37^{\circ} \mathrm{C}$ dapat diperoleh besarnya nilai TFC yaitu sebagai berikut.

$$
\begin{aligned}
T F C & =\frac{P_{M P P \text { saat suhu naik }{ }^{0} \mathrm{C}}}{P_{M P P}} \\
& =\frac{81,5}{100} \\
& =0,815
\end{aligned}
$$

Pada penelitian ini insolasi harian matahari menggunakan insolasi rata-rata harian terkecil pada saat pengukuran yaitu sebesar 4516,33 $\mathrm{Wh} / \mathrm{m}^{2}$ atau $4,516 \mathrm{kWh} / \mathrm{m}^{2}$ dan efisiensi kerja sebesar $90 \%$. Beban yang akan disuplai inverter sebesar 2620 diperoleh dengan persamaan sebagai berikut.

$$
\begin{aligned}
E L & =\text { PVarea } \times \text { Gav } \times \eta p v \times \text { TCF } \times \text { nout } \\
& =6273,87 \times 4,516 \times 0,1261 \times 0,815 \times 0,9 \\
& =2620,624 \mathrm{~kW} / \text { ari }
\end{aligned}
$$

Pada penelitian ini menggunakan presentasi asumsi losses yang menggunakan peralatan baru menurut (Custer, 2012) sebesar $15 \%$. Kebutuhan beban yang disuplai PLTS dihitung dengan persamaan sebagai berikut.

$$
\begin{aligned}
\text { Et } \quad= & \text { Kebutuhan Energi Listrik + Kerugian } \\
& \text { sistem } \\
= & \text { Kebutuhan Energi Listrik }+(15 \% \mathrm{x} \\
& \text { Kebutuhan Energi Listrik }) \\
= & 2620,624+(15 \% \mathrm{x} 2620,624) \\
= & 3013,718 \mathrm{kWh}
\end{aligned}
$$

Berdasarkan kebutuhan beban yang harus

\begin{tabular}{|c|c|c|c|}
\hline Perumahan & $\begin{array}{l}\text { Beban } \\
\text { disuplai } \\
(\mathbf{k W})\end{array}$ & $\begin{array}{l}\text { Kapasitas } \\
\text { Minimum } \\
\text { Inverter } \\
(\mathbf{k W})\end{array}$ & $\begin{array}{l}\text { Jumlah } \\
\text { Kebutuhan } \\
\text { Inverter }\end{array}$ \\
\hline \multicolumn{4}{|c|}{ Kota Cilegon } \\
\hline $\begin{array}{l}\text { TamanCilegon } \\
\text { Indah }\end{array}$ & 125,572 & 168,82 & 6 \\
\hline MetroCilegon & 362,424 & 487,26 & 17 \\
\hline $\begin{array}{l}\text { PondokCilegon } \\
\text { Indah }\end{array}$ & 19,723 & 26,52 & 1 \\
\hline \multicolumn{4}{|c|}{ Kota Serang } \\
\hline $\begin{array}{l}\text { BumiMutiara } \\
\text { Serang }\end{array}$ & 85,664 & 115,17 & 4 \\
\hline HighlandPark & 8006,003 & 10763,63 & 359 \\
\hline \multicolumn{4}{|c|}{ KabupatenSerang } \\
\hline PuriHijauRegency & 1076,007 & 1446,63 & 49 \\
\hline $\begin{array}{l}\text { Griya Serdang } \\
\text { Indah }\end{array}$ & 1194,896 & 1606,47 & 54 \\
\hline $\begin{array}{l}\text { Griya Permata } \\
\text { Serang }\end{array}$ & 2962,387 & 3982,76 & 133 \\
\hline VillaPemataHijau & 936,963 & 1259,69 & 42 \\
\hline
\end{tabular}
disuplai inverter maka kapasitas minimum inverter diperoleh dari persamaan (10) sebagai berikut.

$$
\begin{aligned}
P & =\frac{E L_{B P} \times F M \times E M}{C F} \\
& =\frac{125,572 \mathrm{~kW} \times 1,1 \times 1,1}{0,9} \\
& =168,824 \mathrm{~kW}
\end{aligned}
$$

Pemilihan inverter disesuaikan terhadap rating terdekat dari kapasitas minimum inverter dengan kapasitas inverter yang tersedia dipasaran. Pada penelitian ini menggunakan rating kapasitas inverter $30 \mathrm{~kW}$ dan tegangan sistem 360 Volt. Untuk memenuhi kebutuhan tersebut maka dipilih inverter dengan rating kapasitas $30 \mathrm{~kW}$ sebanyak 6 inverter terhubung paralel dengan input nominal MPP Voltage 360 volt. Adapun kapasitas minimum inverter dan jumlah kebutuhan inverter dapat diamati pada Tabel 5 sebagai berikut.

Tabel 5. Kapasitas Inverter 


\begin{tabular}{lrrc} 
Sankyu & 1307,380 & 1757,70 & 59 \\
Mata Raya & 77,074 & 103,62 & 4 \\
GriyaCilegon & 817,473 & 1099,05 & 37 \\
PesonaCilegon & 2487,709 & 3344,59 & 112 \\
Nusaraya Residence & 174,447 & 234,53 & 8 \\
HarjataniHeritage & 101,642 & 136,65 & 5 \\
PejantenMasEstate & 862,427 & 1159,48 & 39 \\
BumiBaros & 586,240 & 837,60 & 28 \\
Chasanah & 299,820 & 403,09 & 14 \\
BumiWaringinAsi & 788,17 & 27 \\
BumiCikande Indah & 623,007 & & \\
\hline
\end{tabular}

\section{Kapasitas dan Jumlah Panel Surya}

Kapasitas pembangkitan PLTS diperoleh dengan mengalikan luas area array, Peak Solar Insulation (PSI) adalah $1000 \mathrm{~W} / \mathrm{m}^{2}$ dan efisiensi panel surya yaitu sebesar $12,61 \%$ sesuai dengan panel surya yang digunakan pada pengukuran penelitian ini. Besarnya daya pembangkitan PLTS dihitung dengan persamaan (7) sebagai berikut.

$$
\begin{aligned}
P & =6273,87 \mathrm{~m}^{2} \times 1000 \mathrm{~W} / \mathrm{m}^{2} \times 12,61 \% \\
& =791135,007 \mathrm{Wp} \sim 791,135 \mathrm{kWp}
\end{aligned}
$$

Panel surya yang digunakan pada penelitian ini sesuai STC memiliki spesifikasi $\mathrm{P}_{\mathrm{MPP}}$ sebesar $100 \mathrm{~W}$ dengan arus keluaran maksimum $\left(\mathrm{I}_{\mathrm{MP}}\right)$ sebesar 5,84 A dan tegangan keluaran maksimum $\left(\mathrm{V}_{\mathrm{MP}}\right)$ sebesar 17,1 volt. Berdasarkan spesifikasi panel maka jumlah kebutuhan panel surya diperoleh dengan persamaan (8) sebagai berikut.

$$
\begin{aligned}
\text { Jumla Panel } & =\frac{\text { Daya Pembangkitan }(W p)}{\text { Pmpp Panel }} \\
& =\frac{791135 W p}{100 W p} \\
& =7911,35 \sim 7912 \text { Panel }
\end{aligned}
$$

Agar rating tegangan sistem sesuai dengan $360 \mathrm{~V}$ maka pada satu string rangkaian panel surya disusun seri dengan jumlah sebagai berikut.

$$
\begin{aligned}
\text { Jumla panel susun seri } & =360 \mathrm{~V} \div 17,1 \mathrm{~V} \\
& =21,05 \sim 22
\end{aligned}
$$

Total panel surya pada sistem PLTS sebanyak 6469988 Panel tersebut dirangkai sebanyak 22 dengan sususan seri sehingga jumlah string panel surya pada sistem PLTS yang akan dikembangkan dihitung sebagai berikut.

\begin{tabular}{|c|c|c|c|c|}
\hline \multirow[b]{2}{*}{ Perumahan } & \multicolumn{4}{|c|}{ Jumlah Kebutuhan Panel } \\
\hline & $\begin{array}{c}\text { Kapasita } \\
\text { s } \\
(\mathrm{kWp})\end{array}$ & $\begin{array}{c}\text { Susun } \\
\text { an } \\
\text { Paralel }\end{array}$ & $\begin{array}{c}\mathbf{P}_{\mathrm{MPP}} \\
\text { array } \\
(\mathrm{kWp})\end{array}$ & $\begin{array}{c}\text { Jumlah } \\
\text { panel }\end{array}$ \\
\hline \multicolumn{5}{|c|}{ KotaCilegon } \\
\hline Taman Cilegon Indah & 791,135 & 359 & 788,726 & 7898 \\
\hline MetroCilegon & 2283,368 & 1037 & 2278,297 & 22814 \\
\hline PondokCilegon Indah & 124,258 & 56 & 123,032 & 1232 \\
\hline \multicolumn{5}{|c|}{ Kota Serang } \\
\hline BumiMutiara Serang & 539,708 & 245 & 538,267 & 5390 \\
\hline HighlandPark & 50440,000 & 22927 & 50370,802 & 504394 \\
\hline \multicolumn{5}{|c|}{ KabupatenSerang } \\
\hline PuriHijauRegency & 6779,136 & 3081 & 6768,982 & 67782 \\
\hline GriyaSerdang Indah & 7528,170 & 3421 & 7515,964 & 75262 \\
\hline GriyaPermataSerang & 18663,847 & 8483 & 18637,219 & 186626 \\
\hline VillaPermataHijau & 5903,119 & 2683 & 5894,572 & 59026 \\
\hline Sankyu & 8236,852 & 3744 & 8225,598 & 82368 \\
\hline MataRaya & 485,585 & 220 & 483,342 & 4840 \\
\hline GriyaCilegon & 5150,302 & 2341 & 5143,196 & 51502 \\
\hline PesonaCilegon & 15673,246 & 7124 & 15651,485 & 156728 \\
\hline Nusaraya Residence & 1099,062 & 499 & 1096,307 & 10978 \\
\hline Harjatani HeritageE. & 640,374 & 291 & 5894,572 & 6402 \\
\hline PejantenMas & 5433,523 & 2469 & 8225,598 & 54318 \\
\hline BumiBaros Chasanah & 3693,469 & 1678 & 483,342 & 36916 \\
\hline Bumi Waringin Asri & 1888,945 & 858 & 5143,196 & 18876 \\
\hline BumiCikande Indah & 3693,469 & 1678 & 3686,579 & 36916 \\
\hline Jumlah & 141637,285 & & & $\overline{1416162}$ \\
\hline
\end{tabular}

$$
\begin{aligned}
\text { Jumla string panel surya } & =7912 \div 22 \\
& =359,64 \sim 359
\end{aligned}
$$

Energi yang dihasilkan pada rangkaian panel surya tersebut diperhitungkan sebagai berikut.

$$
\begin{aligned}
I_{\mathrm{MPP}} \text { array } & =5,84 \times 359=2096,56 \mathrm{~A} \\
V_{\mathrm{MPP}} \text { array } & =17,1 \times 22=376,2 \mathrm{~V} \\
P_{\mathrm{MPP}} \text { array } & =2096,56 \mathrm{~A} \times 376,2 \mathrm{~V} \\
& =788725,87 \mathrm{~W} \sim 788,73 \mathrm{~kW}
\end{aligned}
$$

Tabel 6. Kebutuhan panel surya

\section{Orientasi Panel Surya}

Berdasarkan hasil penelitian Hardiansyah (2012) dengan menggunkan solar tracker diperoleh sudut azimuth optimum panel surya untuk Serang Cilegon sebesar $-15^{0}$ dari barat. Adapun ilustrasi orientasi panel surya dapat diamati pada Gambar 8 sebagai berikut. 


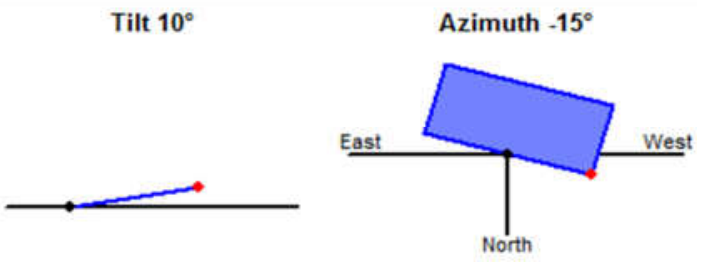

Gambar 8. Orientasi panel surya

\section{E. Kapasitas Baterai}

Kapasitas baterai dapat dihitung dengan persamaan (9) sebagai berikut.

$$
\begin{aligned}
& =\frac{7871,2 \mathrm{~kW} / \text { ari }}{(0,8) \times(0,815) \times(360)} \times 3 \\
& =100603,272 \mathrm{Ah}
\end{aligned}
$$

Kebutuhan kapasitas baterai 100603,272 Ah pada penelitian ini menggunakan baterai dengan kapasitas 1156Ah dengan tegangan 6 Volt. Untuk memenuhi tegangan $360 \mathrm{~V}$ maka dibutuhkan 87,03 $\sim 88$ string dengan setiap string terdiri atas 60 baterai terangkai seri. Sehingga kebutuhan total baterai pada sistem PLTS sebanyak 5280 unit.

\section{F. Analisis Biaya PLTS}

Berdasarkan hasil perhitungan investasi awal untuk salah satu perumahan yaitu sebesar \$ 8675567. Besarnya Biaya operasional dan pemeliharaan PLTS setiap tahunnya (M) adalah sebagai berikut.

$$
\begin{aligned}
(\mathrm{M}) & =1 \% \times \text { Biaya Investasi Awal } \\
& =1 \% \times 8675567 \\
& =\$ 86755,67
\end{aligned}
$$

Pada penelitian ini suku bunga kredit sebesar 10,04\%. Besarnya nilai sekarang untuk biaya jangka panjang operasional dan pemeliharaan $\left(\mathrm{M}_{\mathrm{pw}}\right)$ diperoleh dengan perhitungan sebagai berikut.

$$
\begin{aligned}
\mathrm{M}_{\mathrm{pw}} & =A\left[\frac{(1+i)^{\mathrm{n}} \quad 1}{i(1+i)^{\mathrm{n}}}\right] \\
& =86755,67\left[\frac{(1+0,1004)^{25}}{0,1004(1+0,1004)^{25}}\right] \\
& =\$ 785068,91
\end{aligned}
$$

Biaya siklus hidup dari PLTS yang akan dikembangkan di kawasan perumahan Serang Cilegon berdasarkan biaya investasi awal (C) dan perhitungan Mpw. adalah sebagai berikut.

$$
\begin{aligned}
L C C & =C+M_{P W} \\
& =86755,67+785068,91 \\
& =\$ 9460635,91
\end{aligned}
$$

Biaya energi (cost of energy) suatu sistem PLTS dipengaruhi oleh biaya siklus hidup (LCC), faktor pemulihan modal (CRF) dan kWh produksi tahunan. Faktor pemulihan modal merupakan konversi semua arus kas biaya siklus hidup (LCC) menjadi biaya tahunan.

Faktor pemulihan modal CRF diperoleh dengan persamaan (11) sebagai berikut.

$$
\begin{aligned}
C R F & =\frac{i(1+i)^{\mathrm{n}}}{(1+i)^{\mathrm{n}} 1} \\
\quad & =\frac{0,1004(1+0,1004)^{25}}{(1+0,1004)^{25} \quad 1}=\frac{1,0977}{9,934}=0,1105
\end{aligned}
$$

\begin{tabular}{|c|c|c|c|}
\hline \multirow[b]{2}{*}{ Perumahan } & \multicolumn{3}{|c|}{ BiayaPLTS } \\
\hline & $\begin{array}{c}\text { Investasi } \\
\text { Awal } \\
\text { (US\$) }\end{array}$ & $\begin{array}{l}\mathbf{M}_{\mathbf{P W}} \\
\text { (USS) }\end{array}$ & $\begin{array}{l}\text { LCC } \\
\text { (US\$) }\end{array}$ \\
\hline \multicolumn{4}{|c|}{ KotaCilegon } \\
\hline TamanCilegon Indah & 8675567 & 785068,91 & 9460635,91 \\
\hline MetroCilegon & 7745081 & 700867,42 & 8445948,42 \\
\hline PondokCilegonIndah & 31500563 & 2850547,14 & 34351110,14 \\
\hline \multicolumn{4}{|c|}{ KotaSerang } \\
\hline BumiMutiara Serang & 1988195 & 179915,63 & 2168110,63 \\
\hline HighlandPark & 65871921 & 5960878,09 & 71832799,09 \\
\hline \multicolumn{4}{|c|}{ KabupatenSerang } \\
\hline PuriHijauRegency & 8987593 & 813304,75 & 9800897,75 \\
\hline Griya Serdang Indah & 29909463 & 2706565,41 & 32616028,41 \\
\hline GriyaPermata Serang & 28866269 & 2612164,75 & 31478433,75 \\
\hline VillaPermataHijau & 9199059 & 832440,72 & 10031499,72 \\
\hline Sankyu & 16216027 & 1467419,78 & 17683446,78 \\
\hline
\end{tabular}

$\mathrm{kWh}$ produksi tahunan pada sistem PLTS yang akan dikembangkan di kawasan perumahan Taman Cilegon Indah diperoleh dari hasil simulasi yaitu $553658 \mathrm{kWh}$. Berdasarkan hasil perhitunan LCC, CRF dan $\mathrm{kWh}$ produksi tahun sistem PLTS maka diperoleh biaya energy (COE) dengan persamaan (12) sebagai berikut.

$$
\begin{aligned}
\text { COE } & =\frac{L C C \times C R F}{A k W} \\
& =\frac{9460635,91 \times 0,1105}{553658} \\
& =\$ 1,888 / \mathrm{kW}
\end{aligned}
$$

Tabel 7. Biaya investasi PLTS kawasan perumahan Serang Cilegon 


\begin{tabular}{lrrr} 
MataRaya & 1137045 & 102893,41 & 1239938,41 \\
Griya Cilegon & 10271553 & 929492,78 & 11201045,78 \\
PesonaCilegon & 23132297 & 2093286,49 & 25225583,49 \\
Nusaraya Residence & 1899507 & 171890,08 & 2071397,08 \\
HajjataniHeritage & 4997533 & 452236,47 & 5449769,47 \\
PejantenMas & 9313177 & 842767,48 & 10155944,48 \\
BumiBarosChasamah & 5423837 & 490813,55 & 5914650,55 \\
Bumi WaringinAsri & 6728629 & 608886,71 & 7337515,71 \\
\hline BumiCikandeIndah & 8019219 & 725674,70 & 8744893,70 \\
\hline
\end{tabular}

Net present value (NPV) pada sistem PLTS yang akan dikembangkan dengan suku bunga kredit bank 10,04\% maka diperoleh dengan persamaan (13) sebagai berikut.

$$
N P V=\sum_{t=1}^{n} \frac{\mathrm{NCF}_{\mathrm{t}}}{(1+\mathrm{i})^{\mathrm{t}}}
$$

$\mathrm{NCF}_{\mathrm{t}}$ merupakan perkalian antara $\mathrm{kWh}$ produksi tahunan sistem PLTS dan biaya energi. Sehingga $\mathrm{NCF}_{\mathrm{t}}$ adalah sebagai berikut.

$$
\begin{aligned}
\text { NCFt } & =\left(\begin{array}{lll}
A k W & x C O E
\end{array}\right) \quad M \\
& =\left(\begin{array}{ll}
553658 \times 1,888
\end{array}\right) \quad 86755,67 \\
& =\$ 958644,598
\end{aligned}
$$

Berdasarkan perhitungan $\mathrm{NCF}_{\mathrm{t}}$ maka NPV pengembangan sistem PLTS adalah sebagai berikut.

$$
\begin{aligned}
N P V & =958644,598 \times \frac{1}{(1+0,1004)^{l}} \\
& =\$ 871178,297
\end{aligned}
$$

Perhitungan Discounted Payback Period (DPP) diperoleh dengan menghitung periode nilai sekarang arus kas bersih kumulatif (Kumulatif PVNCF) dalam tahun akan sama dengan nilai investasi awal. berdasarkan arus kas bahwa pada tahun ke-25, Kumulatif PVNCF mendekati nilai investasi awal dengan kekurangan sebesar US\$ 605,814. Selisih Kumulatif PVNCF tahun ke-25 dan tahun ke-26 adalah sebesar US\$ 79678,749. Untuk dapat menutupi kekurangan tersebut maka diperhitungkan dengan 605,814/79678,749= 0,076 dari 12 bulan maka diperlukan sekitar 1 bulan.

DPP dengan jangka waktu 25 tahun 1 bulan menunjukkan bahwa investasi yang akan dikembangkan di kawasan perumahan Serang Cilegon tidak layak untuk dilaksanakan. Hal ini disebabkan waktu DPP lebih besar dari periode umur proyek yang ditetapkan selama 25 tahun.

\section{G. Kontribusi}

Kontribusi energi matahari di kawasan perumahan Serang Cilegon dilakukan dengan software PvSyst untuk memperoleh energi konversi panel surya dan energi suplai yang akan disalurkan ke beban rumah tangga di kawasan perumahan Serang Cilegon. Kontribusi merupakan perbandingan antara beban energi di kawasan perumahan Serang Cilegon dengan

\begin{tabular}{|c|c|c|c|}
\hline Perumahan & $\begin{array}{c}\text { Energi } \\
\text { Konversi }\end{array}$ & Energi Suplai & Kontribusi \\
\hline TamanCilegon Indah & 602203 & 553658 & $19,27 \%$ \\
\hline MetroCilegon & 1715881 & 1577579 & $86,19 \%$ \\
\hline PondokCilegon Indah & 98387 & 90452 & $0,76 \%$ \\
\hline BumiMutiara Serang & 404211 & 371632 & $76,87 \%$ \\
\hline HighlandPark & 36707706 & 33750047 & Tepenuhi \\
\hline PuriHijauRegency & 4988602 & 4586608 & Tepenuhi \\
\hline Griya Serdang Indah & 5509174 & 5065257 & Tepenuhi \\
\hline GriyaPermata Serang & 13594409 & 12499054 & Terpenuhi \\
\hline VillaPermataHijau & 4294821 & 3948774 & Terpenuhi \\
\hline Sankyu & 6022074 & 5536834 & Terpenuhi \\
\hline MataRaya & 391344 & 359775 & Terpenuhi \\
\hline GriyaCilegon & 3773453 & 3469394 & Teppenuhi \\
\hline Pesona Cilegon & 11439204 & 10517486 & Terpenuhi \\
\hline Nusaraya Residence & 812629 & 747141 & Terpenuhi \\
\hline Harjatani Heritage & 497725 & 457594 & $29,37 \%$ \\
\hline PejantenMas & 3978077 & 3657531 & Tepenuhi \\
\hline BumiBaros Chasanah & 2861138 & 2630603 & Tepenuhi \\
\hline Bumi Waringin Asri & 1414974 & 1300930 & $80,19 \%$ \\
\hline BumiCikandeIndah & 2739794 & 2518996 & Tepenuhi \\
\hline
\end{tabular}
energi yang disuplai PLTS. Adapun kontribusi energi dengan insolasi matahari dan temperatur berdasarkan data BMKG Serang dapat diamati pada Tabel 8 sebagai berikut.

Tabel 8. Kontribusi energi matahari

Berdasarkan data Insolasi matahari hasil pengujian dan temperatur panel surya dapat

\begin{tabular}{|c|c|c|c|c|c|c|}
\hline \multirow{3}{*}{ Perumahan } & \multicolumn{6}{|c|}{ Kontribusi HasilPengujian } \\
\hline & \multicolumn{2}{|c|}{ Maret } & \multicolumn{2}{|c|}{ April } & \multicolumn{2}{|c|}{ Mei } \\
\hline & kWh & $\%$ & $\mathbf{k W h}$ & $\%$ & $\mathbf{k W h}$ & $\%$ \\
\hline Taman Cilegon Indah & 47530 & 19,91 & 47631 & 1848 & 47488 & 17,71 \\
\hline MetroCilegon & 135506 & 96,16 & 135590 & 91,58 & 13516 & 81,87 \\
\hline PondokCilegon Indah & 7742 & 0,83 & 7808 & 0,78 & 789 & 0,75 \\
\hline BumiMutiaraSerang & 31925 & 90,82 & 31935 & 73,83 & 31836 & 71,1 \\
\hline HighlandPark & 2903581 & 3,5 & 2893947 & 3,74 & 2886283 & 42 \\
\hline PuriHijauRegency & 394387 & 3,97 & 393591 & 4,09 & 392470 & 4,36 \\
\hline Griya Serdang Indah & 435659 & 69,32 & 434498 & 7428 & 433305 & 80,15 \\
\hline GriyaPermata Serang & 1075274 & 14,34 & 1071816 & 1633 & 1068964 & 17,92 \\
\hline
\end{tabular}
diamati kontribusi suplai energi matahari terhadap beban pemakaian rumah tangga pada bulan Maret, April dan Mei dapat diamati pada Tabel 9 sebagai berikut.

Tabel 9. Kontribusi hasil pengujian 


\begin{tabular}{|l|r|r|r|r|r|r|} 
VillaPermataHijau & 339724 & 18,5 & 338589 & 18,98 & 337693 & 18,94 \\
Sankyu & 476246 & 36,03 & 474911 & 38,94 & 473617 & 41,83 \\
Mata Raya & 30766 & 47,74 & 31092 & 52,60 & 31014 & 56,29 \\
Griya Cilegon & 298387 & 38,07 & 297624 & 41,33 & 296801 & 43,06 \\
Pesona Cilegon & 904724 & 5,60 & 902013 & 621 & 899584 & 6,37 \\
Nusaraya Residence & 64224 & 2271 & 64143 & 24,50 & 63952 & 25,44 \\
Harjatani Heritage & 39245 & 33,69 & 39421 & 30,81 & 39314 & 29,17 \\
PejantenMas & 314574 & 23,50 & 313754 & 29,48 & 312889 & 27,96 \\
BumiBaros Chasanah & 226299 & 6,12 & 225590 & 623 & 224988 & 6,44 \\
Bumi WaringinAsi & 111760 & 83,04 & 111787 & 84,95 & 111440 & 82,22 \\
BumiCikande Indah & 216504 & 48,65 & 212299 & 47,2 & 215646 & 49,99 \\
\hline
\end{tabular}

Insolasi matahari dan temperatur sangat mempengaruhi energi konversi panel surya sehingga berdampak pada energi yang disuplai ke beban.

\section{KESIMPULAN DAN SARAN}

Berdasarkan hasil penelitian dapat disimpulkan bahwa:

1. Pada kawasan perumahan Serang Cilegon sebanyak 19 perumahan berpotensi dalam pengembangan PLTS di area terbuka dengan kapasitas total 84971,481 kWp. Kebutuhan total jumlah panel surya sebanyak 1416162 buah dengan menggunakan panel surya $100 \mathrm{Wp}$ dengan luas area panel surya $0,7936 \mathrm{~m} 2$. Potensi terbesar pada perumahan Highland Park dengan kapasitas sebesar 50370,802 kWp dan potensi terkecil pada perumahan Pondok Cilegon Indah dengan kapasitas sebesar 123,032 kWp. Sudut orientasi panel surya dengan tilt angle 100 dan sudut azimuth -150 dari barat.

2. Investasi PLTS dengan project life selama 25 tahun membutuhkan waktu pengembalian biaya investasi selama 25 tahun 1 bulan terhitung awal berdirinya proyek sehingga tidak layak secara aspek ekonomi

3. Berdasarkan hasil simulasi kontribusi dengan menggunakan data BMKG Serang pada kawasan perumahan Serang Cilegon diperoleh total energi konversi 101845806 $\mathrm{kWh}$ per tahun dan total energi suplai $93639345 \mathrm{kWh}$ per tahun. Total energi konversi dan energi suplai terbesar yaitu pada perumahan Highland Park dengan energi konversi $36707706 \mathrm{kWh}$ per tahun dan energi suplai $33750047 \mathrm{kWh}$ per tahun yang mampu memenuhi kebutuhan energi listrik serta dengan menggunakan data hasil pengujian diperoleh kelebihan energi pada bulan Maret 96,43\%, April 96,26\% dan Mei 95,8\%. Total energi konversi dan energi suplai terkecil yaitu pada perumahan Pondok Cilegon Indah dengan energi konversi $98387 \mathrm{kWh}$ per tahun dan energi suplai $90452 \mathrm{kWh}$ per tahun yang mampu berkontribusi sebesar $0,76 \%$ terhadap kebutuhan energi listrik listrik serta dengan menggunakan data hasil pengujian diperoleh kekurangan energi pada bulan Maret 99,17\%, April 99,22\% dan Mei $99,24 \%$.

Pada penelitian ini masih terdapat kekurangan sehingga diperlukan penelitian lanjutan tentang pengembangan potensi energi matahari yaitu:

1. Penambahan data pengujian yang lebih banyak agar potensi energi pembangkitan PLTS yang dikembangkan lebih akurat.

2. Sebagai studi lanjutan, perlu dilakukan analisa dampak interkoneksi PLTS terhadap kualitas daya jaringan listrik.

\section{REFERENSI}

[1]. Foster, R., Ghassemi, M., Cota, A. (2010). Solar Energy Renewable Energy and The Environment. Boca Raton FL, CRC Press

[2]. Gilbert, M. Masters. (2004). Renewable and Efficient Electric Power Systems Chapter 7 and Chapter 9. Stanford University: A Jhon Wiley \& Sons Inc Publication.

[3]. Pactricia, Hanna. (2012). Analisis keekonomian Kompleks Perumahan Berbasis Energi Sel Surya (Studi Kasus Perumahan Cyber Orchid Town House). Tugas Akhir Teknik Industri Fakultas Teknik Universitas Indonesia

[4]. Permana, Hasno. (2014). Studi Potensi Pembangkit Listrik Tenaga Surya Sebagai Energi Pendukung pada Sistem Kelistrikan di Holtel The Royal Krakatau Cilegon. Skripsi Jurusan Teknik Elektro Fakultas Teknik Universitas Sultan Ageng Tirtayasa 
[5]. Muchammad dan Yohana, Eflita. (2010). Pengaruh Suhu permukaan Photovoiltaic Module 50 Watt Peak terhadap daya Keluaran yang dihasilkan menggunanakan Reflektor dengan variasi sudut reflektor $0^{\circ}, 50^{\circ}, 60^{\circ}, 70^{\circ}, 80^{\circ}$. Jurnal ROTASI - Vol. 12, No. 4, Juli 2010: 1418

[6]. Riyadi, Slamet. 2011. Panel Surya sebagai Energi Alternatif. Universitas Katolik Soegijapranata: Semarang

[7]. Safarudin, Ali Imron. (2013). Studi Pemanfaatan Energi Matahari di Pulau Panjang sebagai Pembangkity Listrik Alternatif. Tugas Akhir Jurusan Teknik Elektro Fakultas Teknik universitas Sultan Ageng Tirtayasa.

[8]. Santiari, I Dewa Ayu Sri. (2011). Studi Pemanfaatan Pembangkit Listrik Tenaga Surya sebagai Catu daya Tambahan pada Industri Perhotelan di Nusa Lembongan Bali. Tesis Jurusan Teknik Elektro Fakultas Teknik Universitas Udayana

[9]. Strzalka, dkk. (2009). Potential of Roof Top PV-systems for Supplying Electricity in Residential Area Scharnhauser Park. Journal IEEE Developments in Renewable Energy Technology ( ICDRET) 2009.

[10]. Zamroni. (2012). Kajian Sistem Penyediaan Energi Listrik Hybrid Sel PV - Diesel di Pulau Sebira Kepulauan Seribu. Jurnal sarjana Institut Teknologi Bandung bidang Teknik Elektro dan Informatika Volume 1, Number 1, April 2012 